The authors examine the promises and prospects of using student engagement data to promote success at minorityserving institutions.

\title{
Student Engagement at Minority- Serving Institutions: Emerging Lessons from the BEAMS Project
}

\author{
Brian K. Bridges, Barbara Cambridge, George D. Kuh,
} Lacey Hawthorne Leegwater

People here talk to you like they care about your life. Everyone is here to help you achieve your goals.

—Winston-Salem State University student

Faculty members do things for you and care, and that makes you want to do better. The quality of work expected was more than I thought I could do.

—University of Texas El Paso student

There is always somebody somewhere to help you.

-Fayetteville State University student

This chapter briefly reviews the prospects and promise of using student engagement data to promote student success at minority-serving institutions (MSIs). Specifically, it draws on examples from colleges and universities in the Building Engagement and Attainment of Minority Students (BEAMS) project-a multiyear joint initiative of the American Association for Higher Education (AAHE) and the National Survey of Student Engagement (NSSE), funded by Lumina Foundation for Education. The 
emphasis here is on what institutions are doing to overcome obstacles to collecting and using data and to implement innovative approaches to institutional change, with student success as the goal.

The student voices heard at the beginning of this chapter and multiple research studies suggest that MSIs can be powerful and nurturing learning environments that provide a safe haven from racial discrimination and value the success of each student. MSIs include historically black colleges and universities (HBCUs), tribal colleges and universities (TCUs), and Hispanic-serving institutions (HSIs). In her landmark study, Fleming (1984) found that HBCUs were more effective than predominantly white institutions (PWIs) in cultivating the skills black students needed to function well in the larger society after college: confidence, motivation, high aspirations, and the ability to thrive in competition. More recent studies have reached a similar conclusion-that HBCUs offer more supportive and positive learning environments for African American students than PWIs (Allen, 1992; Allen, Epps, and Haniff, 1991; DeSousa and Kuh, 1996; Flowers and Pascarella, 1999; Watson and Kuh, 1996).

Similar findings seem to hold for American Indians attending TCUs. The study by D. Brown (2003) of American Indian students who transferred from a two-year TCU to a four-year state university found that students were very satisfied with their experience at the tribal college they attended and recommended that American Indian youth start at a TCU and then move on to a mainstream college or university (see also Dell, 2000; Ortiz and HeavyRunner, 2003). A study commissioned by the American Indian Higher Education Consortium (2000) of TCU graduates concluded that their postsecondary experience had a positive impact on their lives and on the larger American Indian community.

Many reports document the demographic characteristics of Hispanic students, but to our knowledge no published studies focus on the experiences of Hispanic students attending HSIs.

Although the findings we have about MSIs are encouraging, suggesting their positive impact, little systematic attention has been given to examining the student experience with an eye toward using the results for institutional improvement. It is the purpose of this chapter to document examples of MSIs that use student-level data to drive institutional improvement. All the regional accreditation associations, for example, now require evidence of student learning, as well as indications of how this information is being used to improve teaching and learning. Knowing what to do to improve the student experience and institutional effectiveness is nearly impossible without information about the quality of the student experience.

At the same time, it is important that assessment tools be sensitive to the institutional mission, student characteristics, and cultural outcomes considered desirable in the context of MSIs (M. C. Brown, 2003; Ortiz and Boyer, 2003). One of the more popular assessment measures that provides such systemic data is the NSSE. Since 2000, more than 430,000 students at 
more than 850 four-year colleges and universities nationwide have completed the NSSE survey, providing their schools with information about how they use educational resources for learning. The results obtained from these first-year and senior students are being used to improve student persistence and enhance student satisfaction and learning (Kuh, 2003; National Survey of Student Engagement, 2003).

This chapter provides some additional historical perspective on MSIs to illustrate the challenges they have had to overcome in promoting high levels of student engagement and collecting systemic data to drive institutional improvement efforts. Then the BEAMS project is described, followed by some first-order lessons about implementing and using a student engagement survey at MSIs. The chapter closes with institutional examples that illustrate emerging lessons from BEAMS.

\section{History and Role of MSIs}

MSIs date back to the mid-nineteenth century with the establishment of HBCUs following the Civil War. Perhaps the most important event in the early development of HBCUs was the second Morrill Act of 1890, which required states with dual systems of higher education to provide landgrant institutions for both systems (Lucas, 1994; Hoffman, Snyder, and Sonnenberg, 1996). Nineteen HBCUs were eventually organized as landgrant institutions (Hoffman, Snyder, and Sonnenberg, 1996). However, these schools were grossly underfunded and were largely ignored by most southern legislatures (Roebuck and Murty, 1993). The landmark Brown v. Board of Education of Topeka, KS (1954) decision, along with the watershed civil rights movement of the 1950s and 1960s, brought about many changes in American higher education and significantly altered the landscape of HBCUs. Title VI of the Civil Rights Act of 1964, for example, provided the foundation and additional federal support for what Brown began (Jones, 1993). These seminal events opened the doors of colleges and universities to Americans, regardless of race, but, in effect, shrank the pool of HBCU applicants (Redd, 1998; Roebuck and Murty, 1993). It became easier and in some instances more financially attractive for black students to attend PWIs, which produced enrollment shortfalls at many HBCUs, forcing a few schools to close and others to merge with larger mainstream institutions (Thomas and Hill, 1987).

The HSI designation is a fairly recent addition to the higher education landscape, but the skyrocketing growth of the Hispanic population makes HSIs an increasingly important set of higher education providers. The most common definition of an HSI originates from the 1992 Reauthorization of the Higher Education Act (Title III), which requires that 25 percent or more of an institution's students be Hispanic, with at least 50 percent of those students being the first generation in their family to attend college (Benitez, 1998; Laden, 2001). The 1998 Reauthorization of the Act included HSIs 
under Title V, with HBCUs and tribal colleges. Many HSIs are mainstream institutions that have been transformed through demographic enrollment changes, especially in southern and southwestern states, where the burgeoning Hispanic population resides in large numbers (Raines, 1998). Almost half of the nation's HSIs, based on Title III definitions, are located in Puerto Rico (Benitez, 1998). The Hispanic Association of Colleges and Universities (HACU) led the push for greater HSI recognition and funding during the 1990s, spurring the continued annual enrollment growth of these institutions. Between 1990 and 1999, HSI enrollments increased by 14 percent, from about $1,225,000$ to about $1,398,000$, doubling the national percentage increase; the number of degrees awarded grew by 36 percent, or triple the national average (Stearns and Watanabe, 2002).

TCUs emerged in the late twentieth century from the struggle for selfdetermination by American Indian tribes for greater access to postsecondary opportunities that would provide them with needed skills and competencies while at the same time honoring and perpetuating their culture and heritage (Cunningham and Parker, 1998; Spring, 2004). Designated as land-grant colleges by Congress as recently as 1994, the vast majority of TCUs are two-year colleges, are less than twenty-five years old, have small, predominantly American Indian enrollments, are remote and isolated on reservations, have open admissions policies, and are tribally controlled (three are federally chartered institutions) but maintain a separate governing structure (American Indian Higher Education Consortium, 1999; Boyer, 1997). The missions of TCUs primarily focus on providing personalized attention and support that American Indian students might not receive at a distant mainstream institution in their attempt to overcome economic, personal, and social obstacles to educational achievement (Cunningham and Parker, 1998). Despite TCU enrollments doubling fifteen times since 1982 (Harvey, 2002; Ortiz and Boyer, 2003), American Indians still make up only 1 percent of all students enrolled in postsecondary education in America (Ortiz and Boyer, 2003).

Taken together, MSIs contribute richness and diversity to the higher education landscape and stay true to their mission, despite facing challenges. For example, HBCUs make up less than 3 percent of all higher education institutions but enroll approximately 16 to 18 percent of all black college students and continue to graduate a disproportionate percentage26 percent as recently as 1998-of black baccalaureate recipients (Harvey, 2002; Redd, 1998). HSIs, which enroll almost half the Hispanic students in American higher education, award 47 percent of the associate's degrees and 48 percent of the bachelor's degrees earned by Hispanics (Benitez, 1998; Laden, 2001). TCUs provide educational opportunities for more than thirty thousand students annually, or 18 percent of all American Indians in postsecondary education (Boyer, 2002). These statistics are but the tip of the iceberg when estimating the contributions of these institutions and are all the more remarkable when considering the significant hurdles they overcome on a daily basis. 


\section{Challenges Facing MSIs}

Challenges abound for MSIs, with inadequate resources by far the greatest. In 1999-2000, the average in-state, full-time undergraduate tuition at MSIs was 51 percent lower than the average at all institutions (U.S. Department of Education, National Center for Education Statistics, 2000). Because these schools tend to serve a more financially disadvantaged population, they make every effort to maintain low tuition and fees. The current trend toward raising tuition and placing more of the financial burden for college costs on families is another challenge for many students who choose to attend MSIs. Fewer financial resources historically, however, have prevented many MSIs from being able to compete for the best faculty, upgrade and maintain facilities, improve technological infrastructures, and establish large endowments.

In addition to being severely under-resourced, HBCUs must deal with the sometimes unintended consequences of desegregation orders, questions about the viability of the institutions themselves, and enrollment challenges as a result of increased competition for black students from all higher education institutions (Redd, 1998). Although enrollments have increased at most HSIs, the majority are still underfunded, are inadequately staffed, and spend considerably less than the national average on academic instruction, technology, and student support services (Benitez, 1998). Similarly, TCUs struggle constantly to establish financial stability, maintain and upgrade facilities, and recruit and retain faculty (Cunningham and Parker, 1998). These historical and financial obstacles indicate the difficulties these schools have faced and continue to encounter in establishing engaging learning environments that integrate student-level assessments and best educational practices. Despite the significant challenges facing MSIs, they remain an integral component of the higher education landscape, especially for their contributions to minority communities.

\section{Importance of Student Engagement to Student Success}

Although MSIs prepare significant numbers of students of color, little is known about the quality of their students' experiences or their general overall educational effectiveness. The research on college student development shows that the time and energy students at any institution devote to educationally purposeful activities is the greatest predictor of their cognitive and personal development (Astin, 1993; Pascarella and Terenzini, 1991; Pace, 1980). This research also demonstrates that certain positive institutional practices are associated with high levels of student engagement (Chickering and Reisser, 1993; Kuh, Schuh, Whitt, and Associates, 1991; Pascarella and Terenzini, 1991). Perhaps the best-known set of engagement indicators is the "Seven Principles for Good Practice in Undergraduate Education" 
(Chickering and Gamson, 1987). These principles include student-faculty contact, cooperation among students, active learning, prompt feedback, time on task, high expectations, and respect for diverse talents and ways of learning. Also important to achieving positive student learning outcomes are institutional environments that students perceive as inclusive and affirming and in which performance expectations are clearly communicated and set at reasonably high levels (Education Commission of the States, 1995; Kuh, 2001; Kuh, Schuh, Whitt, and Associates, 1991; Pascarella, 2001). These factors and conditions are positively related to student satisfaction and achievement on a variety of dimensions (Astin, 1984, 1993; Goodsell, Maher, and Tinto, 1992; Johnson, Johnson, and Smith, 1991; McKeachie, Pintrich, Lin, and Smith, 1986; Pascarella and Terenzini, 1991; Pike, 1993). Thus educationally effective colleges and universities - those that add value to the student experience-direct students' efforts and energy toward appropriate tasks, activities, and behaviors and engage them in these activities at high levels (Educational Commission of the States, 1995).

Persistence and educational attainment are critical indicators of success after college. Career choices, employment opportunities, and lifelong earning power are directly tied to years of schooling. Education also enhances an individual's upward mobility and fuller participation in our democracy. However, despite the progress made over the last thirty-five years in enrolling more students from historically under-represented groups, a significant gap in educational attainment remains. Compared with 22 percent of white adults who have earned at least a bachelor's degree and 37 percent of Asian Americans, only 16 percent of African American adults, 11 percent of Hispanic adults, and 9 percent of American Indian-Alaskan Native adults have earned postsecondary degrees (U.S. Bureau of the Census, 2000). Of those entering four-year colleges, 20 percent of African Americans and 12.5 percent of Hispanic Americans do not persist in college beyond the first year (U.S. Department of Education, National Center for Education Statistics, 1998). Information is not available for American Indian students. Although students leave college prematurely for multiple reasons, the NCES found that "consistent with Tinto's (1993) theory of academic integration, students who were less able to engage with their academic program were more likely to leave early, even when controlling for such other factors as low GPAs" (U.S. Department of Education, National Center for Education Statistics, 1998, p. 24). Again this illustrates the importance of students engaging with their environment. If institutions want their students to persist, they must offer opportunities and assistance to engage them actively and often.

All institutions are grappling with the same fundamental issue: how to obtain the kind of information that will point to those critical areas where the institution can improve or enhance the quality of the student experience. MSIs face additional challenges, given that many lack the resources to participate in national assessment programs or have the institutional research infrastructures needed to collect and use the results appropriately. 
Surprisingly few schools have effective mechanisms for linking information about student experiences to efforts to improve academic programs and student support services. . . . For student engagement data to have the desired impact at the campus and system levels, a strategic approach is needed that creates supportive networks of institutions grappling with similar types of issues and challenges. While all improvement must inevitably address local concerns and fit the campus culture, some issues are shared across most institutions. One such issue is how to interpret student engagement results in the context of other data an institution has about the quality of teaching and learning. Another issue is how to productively motivate and assist faculty members across academic departments in taking action based on the data. . . Finally, some schools lack the infrastructure to integrate student engagement results with other information about student experience, to disseminate it effectively to various stakeholders, and to design improvement strategies (National Survey of Student Engagement and American Association for Higher Education, 2002, pp. 5-7).

Although NSSE had been recognized as a promising tool for improving institutional effectiveness and student success nationwide, relatively few HBCUs and HSIs had used NSSE in its first three years (2000-2002); at the time, no tribal colleges had participated in this national effort to document best practices. To address this set of issues, AAHE and NSSE joined forces to launch BEAMS.

\section{The BEAMS Project}

The BEAMS initiative is a national partnership to reduce the gap in higher education attainment for African Americans, Hispanics, and American Indians by increasing the numbers of students who achieve their educational objectives. With support from Lumina Foundation for Education, the project brings together the resources of AAHE and NSSE staff to assist these campuses in their efforts to increase student success and learning by using institutional data for campus-based change initiatives.

To generate enthusiasm for the project and better understand how MSIs could more effectively use institutional data to improve, AAHE and NSSE, in 2002, convened a national roundtable of representatives from Lumina Foundation, the Alliance for Equity in Higher Education (hereafter referred to as the Alliance), MSIs, and other pertinent organizations. The focus of the roundtable was to discuss how a project like BEAMS could support institutional improvement and change at MSIs through the use of NSSE data. Because the majority of MSIs had not used NSSE or similar survey instruments, primarily due to costs and concerns about poor response rates, campuses wanted to be assured of receiving assistance to increase response rates, analyze the data, and sustain change efforts over time. 
With these goals in mind, BEAMS was designed to guide and support MSI campuses in undertaking systematic changes that would positively influence student engagement, learning, and success. Two elements are at the core of this effort. The first is obtaining evidence of the kind of student engagement that strongly predicts student success. Student engagement represents what students and what institutions do to prompt their use of effective educational practices (Kuh, 2001; National Survey of Student Engagement, 2001). The following are two examples of engagement activities at the student and institutional level: (1) the amount of time and effort students invest in their studies and other educationally purposeful activities and (2) how an institution deploys its resources, curriculum, learning opportunities, and support services to induce students to participate in activities that lead to the experiences and outcomes that constitute student success. In this context, student success is broadly defined to include persistence, satisfaction, learning, and graduation.

The second design element is the use of consortia to support the change effort. Consortia are an effective means to promote innovation, sustain new practices, and influence others. An upcoming AAHE publication features summary and analysis of the benefits of collaboration in several projects that were supported by The Pew Charitable Trusts, in which Peter Ewell of the National Center for Higher Education Management Systems finds significant improvements in campuses linked together in common work. The existing Alliance institutions provide a pool of MSIs that can benefit from establishing consortia dedicated to improving the conditions for student success.

BEAMS helps campuses enhance student learning and success by first supplying baseline information on the ways in which students currently are engaged in learning at the institution, structuring ways of using institutional data to identify and create action plans to address areas of needed improvement, and providing continued assessment of changes in student learning and success over time.

During the five-year project (2002-2007), approximately 130 four-year MSIs in the Alliance will develop and implement action plans to increase student engagement and attainment within their institutions and to contribute to identifying and collecting effective educational practices for dissemination within and beyond the project. Each participating institution will administer the NSSE survey twice, develop action plans for improving areas revealed through survey results, track and report on improvement, and work with similar campuses in benchmarking groups to share best practices, offer feedback on institutional action plans, and establish student engagement and learning trends across multiple campuses.

For each campus participating in the project, BEAMS financially supports the first administration of NSSE during the project period, participation of a five-member team at one AAHE Summer Academy, follow-up activities both in person and on-line, and opportunities to share emergent 
results from project activities. Specifically, each participating institution agrees to

- Work with NSSE staff to administer the first iteration of NSSE

- Identify areas of work using survey results

- Attend the designated AAHE Summer Academy

- Generate and implement an action plan

- Fund a second NSSE administration following the action plan implementation to monitor progress

- Disseminate outcomes through consortia, the AAHE WebCenter, national forums, and other means chosen by the institution

- Participate in the overall project evaluation

Annually, a new cohort of approximately forty institutions is organized into benchmarking groups of eight to ten campuses to work at an AAHE Summer Academy. Campus grouping is based on the identified NSSE benchmark that the campus project best addressees. Using their NSSE results from the previous years, these institutions

- Identify opportunities for and obstacles to using NSSE data

- Link student engagement results with other relevant institutional information

- Consider institutional structures, policies, and practices that support use of data to improve student success

- Design faculty development activities and noncurricular services to support change

- Work with AAHE and NSSE staff members and representatives from MSI institutions that are high-performing on the NSSE benchmarks in the areas on which group members need improvement

The design of the project includes multiple opportunities for benchmarking group members to represent their institutional and collaborative lessons learned through participating in mid-year meetings, AAHE conferences, and on-line forums. This inter-institutional identification establishes the relationships needed for productive, long-term collaborations-a new opportunity for many institutions in the MSI community.

\section{Work to Date}

As of Spring 2004, two cohorts of campuses had begun work. More than eleven thousand first-year and senior students at the forty-three campuses in the first BEAMS cohort completed NSSE in Spring 2003. Having received results in late summer, participating institutions began to identify improvement priorities during the 2003-2004 academic year. Teams from these 
schools participated in the 2004 AAHE Summer Academy, where they generated action plans to begin implementation in Fall 2004.

A second cohort of thirty-nine campuses administered NSSE in Spring 2004 and are using the 2004-2005 academic year to identify areas for change. These schools will participate in the 2005 AAHE Summer Academy and will begin to implement their action plans in Fall 2005. A final group of approximately forty-five campuses will be identified by Fall 2004, will administer NSSE in Spring 2005, and will participate in the 2006 AAHE Summer Academy.

\section{Intended Outcomes}

The main project focus is to enhance student success through more consistent use of educationally effective policies, practices, and infrastructure development. In addition, the project examines theories in conjunction with actual practice to affirm or modify those theories. Practices need such conceptual bases, and concepts regarding change in postsecondary institutions need to be both applied and questioned by the findings of this project. Thus the project will identify, from its analysis of the progress of campuses, consortia, and the entire project, sets of effective practices and produce a conceptual model of campus change that makes a difference in student persistence and success.

AAHE and NSSE will distribute what is learned in this project through print and Web publications, AAHE meetings, and other national forums; they will work with other disciplinary and professional associations and the AAHE Summer Academy to benefit other institutions that administer NSSE. Through the AAHE-NSSE partnership, the project will advance our understanding of how to increase student persistence and success.

\section{First-Order Lessons}

Some valuable lessons have already been discerned from the first eighteen months of the project. First, securing institutional buy-in was more difficult than anticipated, due largely to the healthy skepticism with which MSIs view such external, outside-in initiatives. Thanks to an extensive campaign in Fall 2002, more than forty MSIs were recruited into the first cohort.

Second, many institutions participating in BEAMS did not maintain current local addresses for their students in a central database-a severe limitation for a large, centrally administered national survey. As a result, at least 17 percent of the original sample could not be contacted. Clearly, many of these campuses were in dire need of developing more reliable databases. Project staff are working to inform future cohorts of the types of information and systems needed for NSSE administration and for additional assessment efforts. Project personnel also provide support through (1) identifying and using innovative efforts to gather this critical student information, (2) helping schools address the technical issues associated with generating acceptable 
return rates, (3) presenting information about creating a team for change, and (4) providing strategies for setting up the best possible environment for engaging in an effective campus action plan based on NSSE data.

Third, although institutions can administer the survey locally, inadequate staffing at MSIs sometimes prevents the proper distribution and collection of hundreds of surveys. Considerable staff time is required to monitor and assist participating institutions to ensure that local administration is carried out effectively. Thus for future administrations, BEAMS staff will carefully assess each participating institution's technological and human resource capabilities and monitor any local administrations of the NSSE survey from a distance. In addition, BEAMS personnel will engage in early and regular conversations with key institutional contacts to determine whether the school's infrastructure is best suited for the centrally administered survey or for local administration.

These difficult structural issues clearly confirm one original premise of the BEAMS project: for many MSIs to make and sustain institutional improvement efforts, their infrastructures will require strengthening. The central goal of the project, which is building capacity at these institutions for assessment and institutional change based on measurable and reliable results, is now viewed as more attainable with this insight and knowledge. Thus the commitment to helping these campuses overcome these structural hurdles and discover ways to use student engagement data to guide improvement has been redoubled. Early reports from several campuses provide cogent examples of why these efforts to achieve and sustain reform are so important.

\section{Institutional Examples}

Institutions in the BEAMS project include colleges and universities that have no prior experience with NSSE, as well as institutions that are building on prior experience with the survey. Norfolk State University, Haskell Indian Nations University, and the University of Texas El Paso (UTEP) are prominent examples in the latter category and are examined in some detail in the section that follows. They have administered NSSE and used their results productively. They will continue to benefit from doing so by participating in the BEAMS project. These three schools discovered new ways to integrate NSSE data with other indicators as they prepared for and implemented change, used data for four common purposes, and advised other BEAMS campuses that are just beginning to use NSSE in their decision-making processes.

\section{Integrating NSSE Data with Other Indicators}

Triangulating different sources of information is a key step in determining the state of student engagement and institutional performance. UTEP, which has over eight years of experience using data to guide policy and decision making, has examined systematically one- and two-year success 
rates, hours successfully completed, and issues that affect incoming students. In 1999, a universitywide effort to support student needs included development of freshman seminars, learning communities, and developmental advising. According to Pablo Arenaz, associate vice president for academic affairs, NSSE data confirmed that the seminars and learning communities have had a surprisingly "huge influence." Based on results from an entering-student survey, an end-of-first-semester evaluation for the freshman seminars, NSSE data, and evaluations by teachers and peer leaders, UTEP is confident about its progress and is identifying other ways to enhance the experience of its first-year students.

Haskell Indian Nations University used a National Institute of Health grant to create a laboratory to assess the mathematics and writing skills of incoming students. Students use the lab to do exercises on-line to improve their skills. According to Myra Alexander Star, dean of the College of Arts and Sciences, the "thumbnail sketches that emerged from the analysis of results of the diagnoses were startling." For example, a consistent pattern of low performance for students who moved from English 090 to 101 and of failure when they advanced to English 102 was explained by the fact that students entering 090 were often performing at the elementary level. Although they advanced through the course to junior-high-level proficiency, that was insufficient to perform adequately in 102. Haskell is trying to decide whether to allow students who have made strides during 090 to enter 101 or to create a senior-high-level course for them. The realization about the junior-high ability level also instigated a pre-entry exam in math and English for all students, with interesting results. Students with general equivalency diplomas (GEDs) score better than students with recent high school diplomas-a contradictory finding from the usual results. Haskell is now integrating the results of these diagnostic tests with its NSSE data in order to make informed decisions about course sequencing. Dean Star notes that Haskell's NSSE scores were better than expected in some areas but identified other areas where improvement is needed and can be targeted.

When Norfolk State discovered through NSSE that it needed to focus on incoming students, it spent a year trying to better understand its students and campus environment. After examining information about the experiences of first-year students, Norfolk State determined that its freshman support apparatus had some strong performing components but that they were not well coordinated. To respond, Norfolk State has instituted a more structured, holistic approach to academic life for its students, especially those in their first year. As one administrator put it, "The centrality of customer service was foregrounded by our NSSE data."

Another example of data triangulation involves Norfolk State's use of the Faculty Survey of Student Engagement (FSSE) to determine faculty expectations. Through exit surveys of graduating seniors, anecdotal information generated by the faculty senate, and the FSSE, Norfolk State discovered divergent views about faculty supplying appropriate and timely 
feedback and about faculty accessibility. The institution is planning a faculty development workshop for the next academic year based on this discovery of a gap in perceptions.

All three institutions have found the NSSE data useful, especially when put in context with other information garnered in multiple ways. Alexei Matveev, associate director of institutional effectiveness and assessment at Norfolk State, expressed it succinctly when he advocated using no information in isolation but employing "a pot of sources of feedback."

Using NSSE Data for Multiple Purposes. Although institutions employ NSSE data in many different ways, UTEP, Haskell, and Norfolk State use their results in at least four similar ways: (1) determining needs of entering and first-year students, (2) identifying obstacles to student progress toward graduation, (3) strategic planning, and (4) representing the institution to external communities.

Determining Needs of Entering and First-Year Students. At Norfolk State, the Office of Academic Affairs and the Academic Council developed workshops, used small discussion groups, and brought in a consultant to help faculty focus on where change may be desired. Areas considered included grading, testing what is taught, and teaching writing as the responsibility of all faculty members. NSSE data can help to keep faculty from becoming complacent about student learning, especially in the first year. One example from the NSSE data was an "alarming realization" about office hours. Although faculty members reported being in their offices during posted hours, students indicated that they wanted faculty available when students felt they needed them. This gap analysis on engagement offers faculty "food for thought," not dictating specific changes as much as providing a starting point for discussion.

In preparation for instituting learning communities, Haskell used outside consultants to analyze whether incoming students were prepared adequately for university-level academic work. In-depth knowledge about students' backgrounds and abilities, partly gained through NSSE, portend well for decisions about curriculum and educational environment.

UTEP's Center for Institutional Evaluation and Assessment disseminated NSSE results widely to deans, chairs, and faculty members. In addition, two presentations (one by a NSSE staff member) were made to the Administrative Forum of seventy to eighty managers, representing all academic and student life units. UTEP realizes that students learn as much, or more, outside the classroom as inside, so the institution takes seriously the totality of students' lives and is supporting closer collaboration between academic and student affairs to strengthen connections between what students do in their academic program and their lives beyond the classroom and the campus. Again, the efforts promote better engagement.

Identifying Obstacles to Student Progress Toward Graduation. At one point, UTEP's NSSE data indicated that although students were engaged at reasonably high levels in the first year of college, and persistence rates 
improved between the first and second year, students became less satisfied with their studies and the campus environment as they progressed. With additional information gathered from senior surveys, UTEP is now looking more closely at senior responses on NSSE. President Natalicio has decided to invite students to help administrators and faculty understand and interpret the NSSE results and to provide suggestions for what UTEP can do to improve the quality of undergraduate education.

Haskell had a lower-than-desired response rate for its seniors in its first administration of NSSE. As a result, the institution plans to combine the results from the next administration of NSSE with other information to estimate the potential of what Star calls "an advancement program." Students come into the university and are retained but perhaps do not advance toward graduation as they should, and Haskell wants to improve its studentsuccess and graduation rate. The problem, therefore, was not so much retention as it was graduation and the need to cipher out variables to help bring about this success measure.

Norfolk State also realized that there is considerable difference between its freshmen and seniors in the areas of student-faculty interaction and supportive campus environment. Administrators and faculty are "educating ourselves as we go" in order to decide how to best foster and support the kinds of interactions and educational environment that promote student success. As issues are identified, the institution takes action to help students engage, learn, and succeed.

Reaching Mission Attainment Through Strategic Planning. All three universities found that NSSE data contributed to better mission definition as they questioned and asserted their core values and purposes. Because the U.S. Bureau of Indian Affairs is unable to fund several vacant faculty positions, Haskell was forced to reexamine how it could more efficiently deploy its current faculty and staff. An open question for debate was, "Are we a high school, or are we a four-year university?" Dean Star notes that the university currently devotes "a whale of a lot of money in high school-level courses" because students matriculate to this open-mission institution inadequately prepared for college-level work. As Haskell looks to its accreditation visit in 2005, it is combining its NSSE data with other information to further clarify its mission and thereby determine which programs to keep and which to discontinue. By refining and sharpening its purpose, Haskell can focus its resources on a more limited and achievable mission.

Norfolk State is also committed to developing a culture of evidence. To this end, it has been using a variety of surveys and focus groups to identify best practices in its context and use this information to revise and sharpen its strategic plan. NSSE in particular has been useful in identifying critical success factors.

UTEP President Natalicio likes NSSE's approach of comparing the university's actual scores against what it is predicted to do, based on student and institutional characteristics. In terms of using this information in planning and decision making, the student engagement results, however, do not 
always immediately point to institutional practices that faculty and staff can change to promote student success. Because being able to plan for student learning depends on sound data, she hopes they can effectively and powerfully translate their NSSE results for various campus constituencies.

Representing the Institution to External Communities. All three institutions are enthusiastic about the utility of their NSSE results for better explaining to external constituents the quality of the undergraduate experience. Two institutions pointed to the debilitating influence of popular comparative ratings like those of U.S. News and World Report because certain measures on which the rankings are based are irrelevant to their individual mission. For example, Norfolk State noted that it is focused not on accumulating research dollars but on providing access. Thus its measure of success needed different data to demonstrate their success, based on their distinct mission. Elsie Barnes, vice president for academic affairs, notes, "NSSE allows us to be able to demonstrate efforts focused on improving students' access and success." Norfolk State believes that external publics sometimes know about the institution but not what it does. For example, when a Virginia newspaper did interviews about NSSE use at colleges and universities throughout the state, Norfolk State was shown to rate highly on civic engagement in relation to most other institutions in the state, thereby demonstrating one of its success indicators. Norfolk State's goal is also to be competitive nationwide, so it is interested in being benchmarked not only with HBCUs but with other master's-granting institutions across the country. The NSSE data allowed the institution to do a better job of displaying and benchmarking its indicators of success.

Natalicio refuses to allow external groups to stereotype UTEP students. Describing the context in which many UTEP students fit their academic lives can sound like an apology or an excuse for low graduation rates. NSSE data, however, allow Natalicio and her colleagues to focus specifically on student persistence and success. This is especially helpful when designing new programs and in evaluating existing ones so that university faculty and staff can more clearly distinguish between the internal things they can do to influence students' academic performance and the student characteristics over which they have no control.

According to Dean Star, Haskell wants information it can use to benchmark against other institutions. Haskell is looking to NSSE as a vehicle to loosen the restrictive yoke of IPEDS data, which up until now provided the only way to compare the institution with other TCUs. Haskell intends to use its NSSE results to compare the experiences of its first-year students to their counterparts at different types of institutions.

\section{Advice for Other BEAMS Campuses}

Drawing on their experiences to date, Norfolk State, UTEP, and Haskell representatives offer the following suggestions to BEAMS campuses, as well as other institutions looking to incorporate NSSE data into institutional improvement efforts: 
1. Combine NSSE data with local sources of information to make evidencebased decisions.

2. Provide opportunities to "let the data" talk to various campus groups, such as using focus groups made up of faculty members, faculty senate leaders, administrative teams, students, and governing board members.

3. Provide faculty and staff development opportunities to consider student engagement results and identify priorities to enhance student success. Such deliberations are essential to create enthusiasm and buy-in for institutional improvement and to sustain related initiatives.

4. Find multiple ways to incorporate student engagement information in campus planning and decision making. For example, when possible use the data for purposes of both improvement and accountability. One caveat: do not fall into the trap of allowing NSSE data to become just one more set of metrics that becomes something akin to a rating system.

5. Use the BEAMS project to learn from other institutions and to share what your institution is doing well and is learning to do better.

\section{Conclusion}

Over the course of the BEAMS project, as many as 140 MSIs will make discoveries about their institutions, generate strategies for change, and increase student engagement and learning. Over the coming years, BEAMS will (1) provide an array of strategies and evidence about their efficacy, (2) build a network of institutions like the University of Texas El Paso, Haskell Indian Nations University, and Norfolk State University that can support one another as they serve their students, and (3) contribute to higher education models of evidence-based decision making that are useful to all colleges and universities.

\section{Notes}

All quoted material about the University of Texas El Paso comes from a February 26, 2004, phone interview with Diana Natalicio, president; Margaret Smith, dean of University College; and Pablo Arenaz, associate vice president for academic affairs.

All quoted material about Haskell Indian Nations University comes from a February 26, 2004, phone interview with Myra Alexander Star, dean of the College of Arts and Sciences.

All quoted material from Norfolk State comes from a February 25, 2004, phone interview with Elsie Barnes, vice president for academic affairs; Nuria Cuevas, associate vice president for academic affairs and director of institutional effectiveness and assessment, and Alexei Matveev, associate director of institutional effectiveness and assessment.

\section{References}

Allen, W. R. "The Color of Success: African American College Student Outcomes at Predominantly White and Historically Black Colleges." Harvard Educational Review, $1992,6(2), 26-44$. 
Allen, W. R., Epps, E. G., and Haniff, N. Z. (eds.). "College in Black and White: African American Students in Predominantly White and in Historically Black Public Universities." Albany: State University of New York Press, 1991.

American Indian Higher Education Consortium. Tribal Colleges: An Introduction. Alexandria, Va.: American Indian Higher Education Consortium, 1999.

American Indian Higher Education Consortium. Creating Role Models for Change: A Survey of Tribal College Graduates. Alexandria, Va.: American Indian Higher Education Consortium, 2000.

Astin, A. W. "Student Involvement: A Developmental Theory for Higher Education." Journal of College Student Personnel, 1984, 25, 297-307.

Astin, A. W. What Matters in College? Four Critical Years Revisited. San Francisco: JosseyBass, 1993.

Benitez, M. "Hispanic-Serving Institutions: Challenges and Opportunities." In J. P. Merisotis and C. T. O'Brien (eds.), Minority-Serving Institutions: Distinct Purposes, Common Goals. New Directions in Higher Education, no. 102. San Francisco: JosseyBass, 1998.

Brown, D. "Tribal Colleges: Playing a Key Role in the Transition from Secondary to Postsecondary Education for American Indian Students." Journal of American Indian Education, 2003, 42(1), 36-45.

Brown, M. C. "Emics and Etics of Researching Black Colleges: Applying Facts and Avoiding Fallacies." In M. C. Brown and J. E. Lane (eds.), Studying Diverse Institutions: Contexts, Challenges, and Considerations. New Directions for Institutional Research, no. 118. San Francisco: Jossey-Bass, 2003.

Brown v. Board of Education, 347 U.S. 483 (1954).

Boyer, P. Native American Colleges: Progress and Prospects. Princeton, N.J.: Carnegie Foundation for the Advancement of Teaching, 1997.

Boyer, P. "Defying the Odds." Tribal College, 2002, 14(2), 12.

Chickering, A. W., and Gamson, Z. F. "Seven Principles for Good Practice in Undergraduate Education." AAHE Bulletin, 1987, 39(7), 3-7.

Chickering, A. W., and Reisser, L. Education and Identity. (2nd ed.) San Francisco: Jossey-Bass, 1993.

Cunningham, A. F., and Parker, C. "Tribal Colleges as Community Institutions and Resources." In J. P. Merisotis and C. T. O'Brien (eds.), Minority-Serving Institutions: Distinct Purposes, Common Goals. New Directions in Higher Education, no. 102. San Francisco: Jossey-Bass, 1998.

Dell, C. A. "The First Semester Experiences of American Indian Transfer Students." Dissertation Abstracts International, 2000, 61(02), 519. (University Microfilms no. 9962226)

DeSousa, D. J., and Kuh, G. D. "Does Institutional Racial Composition Make a Difference in What Black Students Gain from College?" Journal of College Student Development, 1996, 37(3), 257-267.

Education Commission of the States. Making Quality Count in Undergraduate Education. Denver, Colo.: Education Commission of the States, 1995.

Fleming, J. Blacks in College: A Comparative Study of Students' Success in Black and in White Institutions. San Francisco: Jossey-Bass, 1984.

Flowers, L., and Pascarella, E. T. "Does College Racial Composition Influence the Openness to Diversity of African American Students?" Journal of College Student Development, 1999, 40(4), 377-389.

Goodsell, A., Maher, M., and Tinto, V. (eds.). Collaborative Learning: A Sourcebook for Higher Education. University Park: National Center on Postsecondary Teaching, Learning and Assessment, The Pennsylvania State University, 1992.

Harvey, W. B. Nineteenth Annual Status Report on Minorities in Higher Education, 2000-2001. Washington, D.C.: American Council on Education, 2002. 
Hoffman, M., Snyder, T. D., and Sonnenberg, B. Historically Black Colleges and Universities: 1976-1994. (NCES Publication no. 96-902). Washington, D.C.: Government Printing Office, 1996.

Johnson, D. W., Johnson, R., and Smith, K. A. Cooperative Learning: Increasing College Faculty Instructional Productivity. ASHE-ERIC Higher Education Report no. 4. Washington, D.C.: The George Washington University, School of Education and Human Development, 1991.

Jones, D. K. "An Education of Their Own: The Precarious Position of Publicly Supported Black Colleges After United States v. Fordice." Journal of Law and Education, 1993, 22(4), 485-517.

Kuh, G. D. "Characteristics of Involving Colleges." In G. D. Kuh and J. Schuh (eds.), The Role and Contribution of Student Affairs in Involving Colleges. Washington, D.C.: National Association of Student Personnel Administrators, 1991.

Kuh, G. D. "Assessing What Really Matters to Student Learning: Inside the National Survey of Student Engagement." Change, 2001, 33(3), 10-17, 66.

Kuh, G. D. "What We're Learning About Student Engagement from NSSE." Change, 2003, 35(2), 24-32.

Kuh, G. D., Schuh, J. S., Whitt, E. J., and Associates. Involving Colleges: Successful Approaches to Fostering Student Learning and Personal Development Outside the Classroom. San Francisco: Jossey-Bass, 1991.

Laden, B. V. "Hispanic-Serving Institutions: Myths and Realities." Peabody Journal of Education, 2001, 76(1), 73-92.

Lucas, C. J. American Higher Education: A History. New York: St. Martin's Griffin, 1994.

McKeachie, W. J., Pintrich, P. R., Lin, Y., and Smith, D. Teaching and Learning in the College Classroom: A Review of the Research Literature. Ann Arbor: National Center for Research to Improve Postsecondary Teaching and Learning, University of Michigan, 1986.

National Survey of Student Engagement. The National Survey of Student Engagement: Origins and Potential. Bloomington, Ind.: Indiana University Center for Postsecondary Research, 2001.

National Survey of Student Engagement. Converting Data into Action: Expanding the Boundaries of Institutional Improvement. Bloomington, Ind.: Indiana University Center for Postsecondary Research, 2003.

National Survey of Student Engagement and American Association for Higher Education. "Using Evidence of Student Engagement to Promote Student Success and Institutional Improvement." Grant proposal submitted by NSSE staff to Lumina Foundation for Education, 2002.

Ortiz, A. M., and Boyer, P. "Student Assessment in Tribal Colleges." In M. C. Brown and J. E. Lane (eds.), Studying Diverse Institutions: Contexts, Challenges, and Considerations. New Directions for Institutional Research, no. 118. San Francisco: Jossey-Bass, 2003.

Ortiz, A. M., and HeavyRunner, I. "Student Access, Retention, and Success: Models of Inclusion and Support.” In M.K.P. Benham and W. J. Stein (eds.), The Renaissance of American Indian Higher Education. Hillsdale, N.J.: Erlbaum, 2003.

Pace, C. R. "Measuring the Quality of Student Effort." Current Issues in Higher Education, 1980, 2, 10-16.

Pascarella, E. T. "Identifying Excellence in Undergraduate Education: Are We Even Close?" Change, May-June 2001, 19-23.

Pascarella, E. T., and Terenzini, P. T. How College Affects Students: Findings and Insights from Twenty Years of Research. San Francisco: Jossey-Bass, 1991.

Pike, G. R. "The Relationship Between Perceived Learning and Satisfaction with College: An Alternative View." Research in Higher Education, 1993, 34, 23-40.

Raines, R. T. "Collaboration and Cooperation Among Minority Serving Institutions." In J. P. Merisotis and C. T. O'Brien (eds.), Minority-Serving Institutions: Distinct Purposes, 
Common Goals. New Directions in Higher Education, no. 102. San Francisco: JosseyBass, 1998.

Redd, K. E. "Historically Black Colleges and Universities: Making a Comeback." In J. P. Merisotis and C. T. O'Brien (eds.), Minority-Serving Institutions: Distinct Purposes, Common Goals. New Directions in Higher Education, no. 102. San Francisco: JosseyBass, 1998.

Roebuck, J. B., and Murty, K. S. Historically Black Colleges and Universities: Their Place in American Higher Education. Westport, Conn.: Praeger, 1993.

Spring, J. Deculturalization and the Struggle for Equality: A Brief History of the Education of Dominated Cultures in the United States. (4th ed.) Boston: McGraw Hill, 2004.

Stearns, C., and Watanabe, S. Hispanic Serving Institutions: Statistical Trends from 1990 to 1999. (NCES Report no. 2002-051). Washington, D.C.: National Center for Education Statistics, 2002.

Thomas, G. E., and Hill, S. "Black Institutions in Higher Education: Present Roles, Contributions, Future Projections." Journal of College Student Personnel, 1987, 28(6), 496-503.

U.S. Bureau of the Census. Census 2000 Supplemental Survey. [http://www.census. gov/ACS/WWW] 2000.

U.S. Department of Education, National Center for Education Statistics. Stopouts or Stayouts? Undergraduates Who Leave College in Their First Year. Washington, D.C.: Government Printing Office, 1998.

U.S. Department of Education, National Center for Education Statistics (NCES). Integrated Postsecondary Education Data System (IPEDS). Finance Survey, Fiscal Year 2000.

Watson, L. W., and Kuh, G. D. "The Influence of Dominant Race Environments on Student Involvement, Perceptions, and Educational Gains: A Look at Historically Black and Predominantly White Liberal Arts Institutions." Journal of College Student Development, 1996, 37(4), 415-424.

BRIAN K. BRIDGES is associate director of the Indiana University Center for Postsecondary Research and the Building Engagement and Attainment of Minority Students (BEAMS) Project.

BARBARA CAMBRIDGE is vice president for fields of inquiry and action and director of the BEAMS project at the American Association for Higher Education.

GEORGE D. KUH is Chancellor's Professor of Higher Education and director of the Center for Postsecondary Research at Indiana University. His research interests include assessing student and institutional performance to improve the quality of the undergraduate experience.

LACEY HAWTHORNE LEEGWATER is assistant director of the Building Engagement and Attainment for Minority Students (BEAMS) Project at the American Association for Higher Education, Washington, D.C. 